between II and $12 \mathrm{~km}$. is $20 \mathrm{~mm}$. at Manchester and $28 \mathrm{~mm}$. at Pyrton Hill, which has a higher temperature at that height. Similar differences occur between $I_{3}$ and $\mathrm{I}_{4} \mathrm{~km}$., and between 5 and $6 \mathrm{~km}$.

Great difficulty is experienced in reconciling the temperature observations with the observed and expected decrease in wind velocity in the advective region. The obvious errors noted above may be partly responsible for the extraordinary velocity of 150 m.p.s., found from the horizontal gradient of pressure at $16 \mathrm{~km}$. But apart from errors of calculation, an error of only $\mathrm{I}^{\circ} \mathrm{C}$. in the mean temperature of the air column would produce an error of nearly $3 \mathrm{~mm}$. in the pressure at $16 \mathrm{~km}$. It must also be remembered that where convection is prevented the condition of steady motion may never be reached, and the differences of pressure may be equalised by translation of air across the isobars with moderate velocity.

Dr. Shaw finds that if the lower surface of the advective region is depressed owing to a disturbance in the lower atmosphere, there will be an increase of temperature of $9^{\circ} \mathrm{C}$. per $\mathrm{km}$. of depression. Such a depression would presumably be propagated with the same velocity as the disturbance, but the obstacles to convection in the advective region may make the upper portion of the atmosphere act as a damping agent by which the disturbance would be annulled.

The mean, maximum, and minimum values of $H_{c}$ and $T_{c}$, the height and temperature at which the advective region begins, are given in the table:-

$$
\text { Nean } \mathrm{H}_{\mathrm{c}} \text { Mean } \mathrm{T}_{\mathrm{c}}
$$

Pyrton Hill $\left.12^{\circ} \mathrm{km} .219^{\circ} \mathrm{A}\right)$ Max. $15^{\circ} 2 \mathrm{~km} .24 \mathrm{1}^{\circ} \mathrm{A}$ $\begin{array}{llllll}\text { Ditcham ... } 122^{\circ}, " & 221^{\circ}, " & \text { Min. } 7.8, & 234^{\circ},\end{array}$

The values are higher than the mean values found by the present writer and Harwood. The difference probably arises partly through the method of fixing $\mathrm{H}_{c}$, partly owing to the exclusion of the 1909 results from the present report.

It is a pleasure to note that pressure is expressed in megadynes per $\mathrm{cm}^{2}$, and temperature in degrees C. above the absolute zero. The report is full of interest to all engaged in upper-air research, and will be especially useful to those who are contemplating the establishment mental stations.

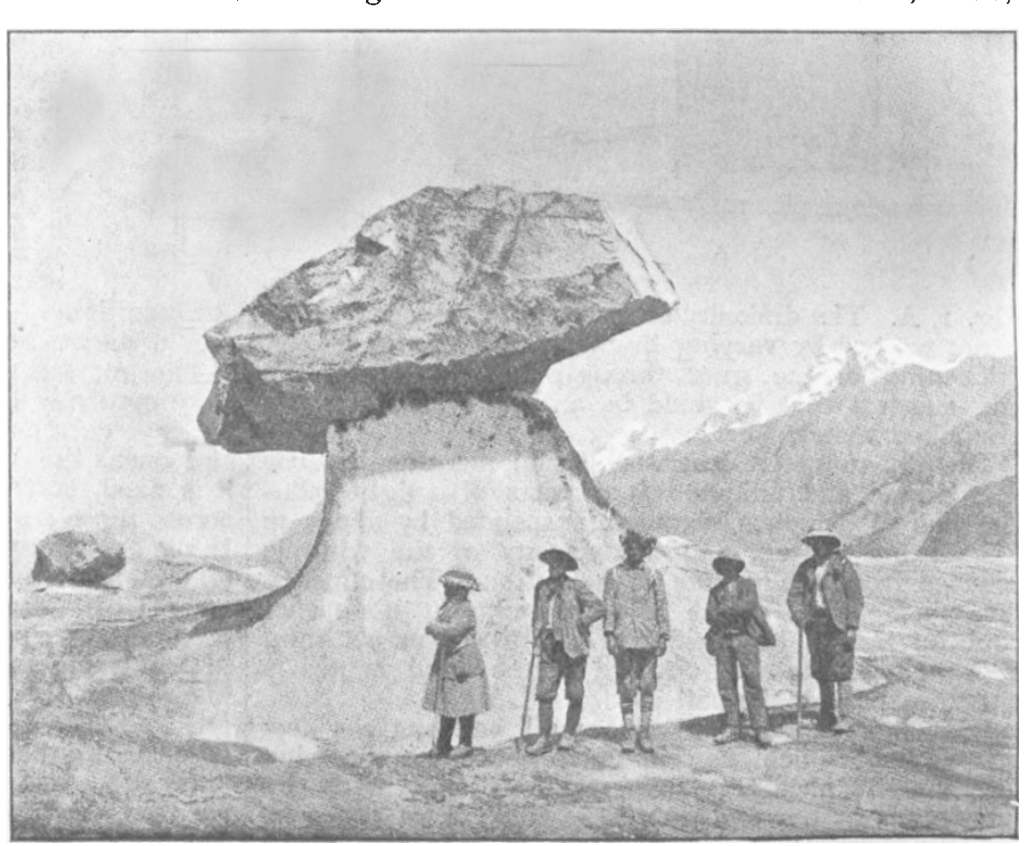

Fig. r.-A g'acier-table of unusual size met with on the lowest third of the Biafo Glacier at an altitude of about 3660 metres (12,0no feet). The rock-boulder was 5 metres (16.4 feet) long, the ice-pedestal $3^{\circ} 8$ metres ( $12^{\circ} 46$ feet) high, and the height of the whole $5{ }^{\circ} 5$ metres ( 8 feet)
a table with mu.h lower pedestal seen in distance at left. (From the Geographical Journal.)

watersheds of Asia. Here that is gashed by rather short and steep transverse valleys, altogether nine in number, and attains an elevation of ten exceeding 20,000 feet above sea-level. On the southern side is another mountain wall, not quite so lofty, though even its lowest point is quite a thousand feet above the summit of Mont Blanc. From its western part-rather more than fifteen miles in extent-six tributary glaciersthree of them large--descend to the Hispar, but its eastern and upper portion-fully twenty-one miles in length-is practically unbroken. A rather long and flat snow saddle, I7,500 feet above sea-level, parts the Hispar from the Biafo Glacier, which descends towards the south-east, and the total length of the former, from its termination near Hispar village, at a height of about II,Ooo feet above sea-level, is, accordng to Dr. Workman's measurement, a little less than thirty-seven miles, or a mile and a half greater than that assigned to it by Drs. Calciati and Koncza.

The pass over the Hispar and Biafo glaciers, according to Lieut.-Colonel Grodwin-Austen, who,

\section{THE HISPAR GLACIER.'}

$D^{R}$. AND MRS. BULLOCK WORKMAN, the well-known explorers of the higher Himalayas, have read before the Royal Geographical Society a most interesting account of the Hispar Glacier. This is one of a group of four of the world's greatest mountain-glaciers, which, together with two others of them-the Biafo and the Chogo Lungma-and some of their tributaries, have been explored from end to end by these indomitable climbers. The Hispar Glacier, one of the many feeders of the Indus, occupies a long and nearly straight valley, running roughly parallel with the crest of the Karakoram-one of the

1 The Hispar Glacier. I. Its Tributaries and Mountains. By Fanny
Bullock Workman. Ii. Prominent Features of its Structure. By Bullock Workman. Ii. Prominent Features of its Structure. By William Hunter Workman. (Gesgraphical Journal, vol. xxxv., pp.
ro5-3i, February, rgro.)

$$
\text { NO. } 2 \text { II } 2, \text { VOL. 83] }
$$

about half a century ago, explored these ice-clad fastnesses, was in former times occasionally used by natives, especially marauders, but when Sir Martin Conway traversed it in $1892^{1}$ he found the traditions were very vague. The only serious difficulties are those due to the length of the journey at such a considerable height above sea-level. These, however, did not prevent Dr. and Mrs. Workman from spending several weeks on their way over the pass from Hispar village to Askole, and carefully studying this ice-clad region.

The Hispar Glacier has a low gradient-on the whole about one in thirty-and its average width is a little less than two miles. It receives, as has been said, six large tributaries from the northern side, and three, also large, on the lower part of its southern side. All, and especially the former, are laden with débris to an unusual extent. The effect of this is

1 See "Climbing and Exploration in the Karakoram-Himalayas," by W. M. Co.zway, chapters xyi-xix. (1894.) 
plainly visible on the trunk stream. Here, for a distance of nearly fifteen miles above its end, the whole surface "is broken into ice hillocks, separated by deep depressions and heavily coated with débris of every size from mud and sand to granite blocks 20 to 50 feet in diameter," such as may be seen in the gigantic glacier-table, for the picture of which (Fig. I) we are indebted to the Royal Geographical Society. From slightly below the entrance of the Haigatum tributary a band of white ice appears among these hillocks, which broadens out as it rises until it occupies all the southern side of the glacier. On the northern side the hillocks persist for eleven and a half miles farther up. They vary in height from about 50 to 230 feet, or even more, and sometimes recall drumlins in their linear arrangement and form. Beyond these hillocks the ice, as would be expected, is fairly free from débris. In the other parts, while the lateral moraines are large, medial moraines are practically absent.

The surface exhibits some other peculiarities. Over two-thirds of its area lakelets, occupying ice-basins,

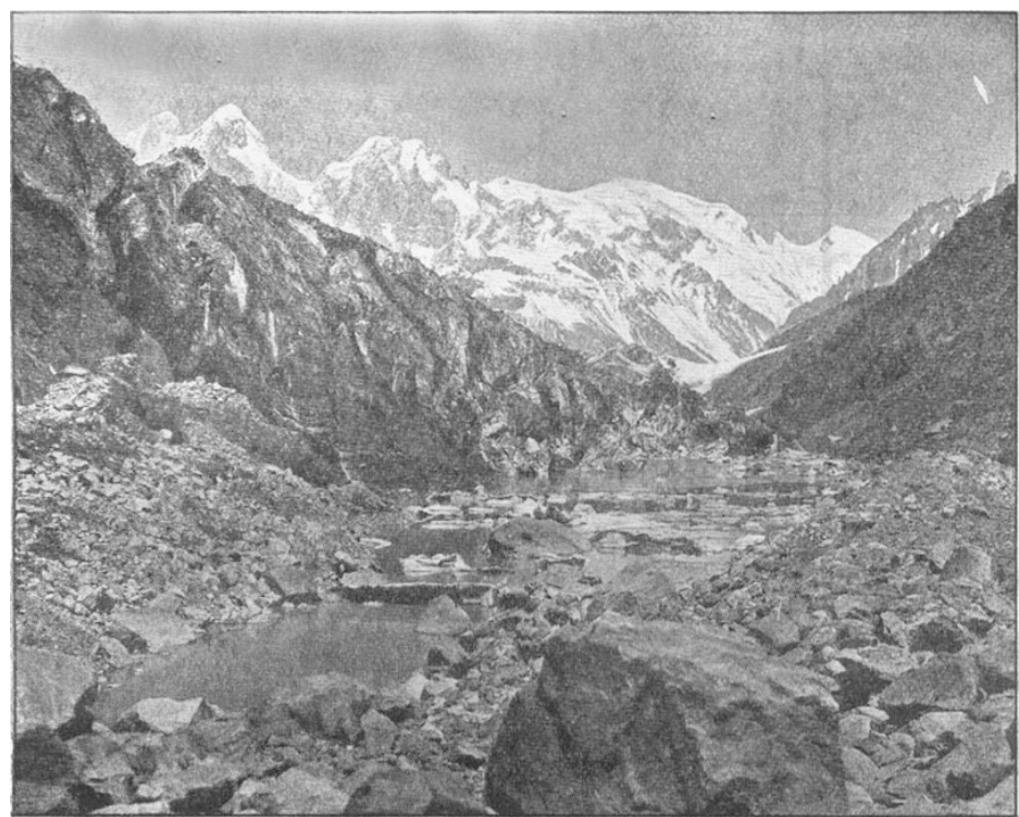

FIG. 2.-A border-lake near the junction of the Jutmaru with the Hispar Glacier. It is enclosed by a lateral moraine and the mountain-wall on the right, and the high side of the Jutmaru.Glacier on the left, from which the ice-fragments floating on the water are de ived. The stratification of the blackened glacial ice is well seen. Behind are the high snow-peaks walling in the Jutmaru. (From the Gergraphical Jonnal)

are unusually common. Thus, as might be anticipated, it is but little crevassed. In fact, the only icefall is at the beginning of the descent from the actual pass, where the subglacial valley floor naturally steepens. In these circumstances the "hummocky" surface appears at first sight arromalous, but of this Dr. Workman offers a satisfactory explanation. The trunk stream of the Hispar receives at least a dozen tributary glaciers, most of them large. The valley, however, is a trench of only moderate breadth, bounded by steep, rocky walls. As the side streams are too strong to be ponded back by the main one, they force their way downwards side by side with it. Thus the pressure becomes greater than the resisting power of the ice, and this is squeezed upwards into ridges and protuberances. These are favourable to the formation of lakelets, which extend up to an elevation of about 16,000 feet, surface streams being correspondingly rare. Other lakelets, formed by dams of ice or moraine, occur at the side of the NO, 2 I 12 , VOL. 83 ]
Hispar and its tributaries, as may be seen in Fig. 2. Intra-glacial moraines, due to the excretion of débris which has been engulfed in large crevasses, may also be observed, as well as the usual structures of névé and glacier-ice.

The scenery of this region of snowy peaks and giant glaciers has a general resemblance, though on a grander scale, to that of the Alps and the Caucasus, and its dominant outlines are indicative of the action of fluviatile rather than of glacial erosion. It is also worth noting that, notwithstanding the troughlike shape of the valley occupied by the Hispar icestream, neither the map nor the photographs suggest any marked truncation of the spurs past which it moves. Yet here, where several ice-streams are crowded into a comparatively narrow corridor, we might expect to find its rocky wall even undercut by their struggle to force a passage. The Hispar Glacier was one of several on which in 1906 the Geological Survey of India fixed marks in order to study their advance and retreat. It then appeared to be practically stationary, and had thus continued to the time of Dr. Workman's visit. So, too, had the Yengutsa Glacier, which reaches the valley-fioor a little below the end of the Hispar. Yet, about five years prior to 1906 , it had rapidly advanced for a distance of nearly two miles. One minor point of interest may be mentioned. Grouped spires or pyramids of snow or ice were not seldom observed, resembling the niéves penitentes of the Andes, to which Dr. Workman, though not without protest from Sir Martin Conway, extends the name.

\section{T. G. BONNEY}

\section{HALLEY'S COMET.}

SINCE its conjunction with the $S$ sun Halley's comet has been seen from several observatories, and on April 16 was seen with the naledeve by the observers at Cape Town. Thus there is some reason for hoping that, given clear morning skies, the comet may become easily observable in England, although its low altitude at sunrise, until after it has transitted the sun on May I9, is not favourable.

The following is part of the ephemeris calculated for April and May by Dr. Smart, and communicated by Mr. Crommelin to the Astronomische Nachrichten (No. 4379):-

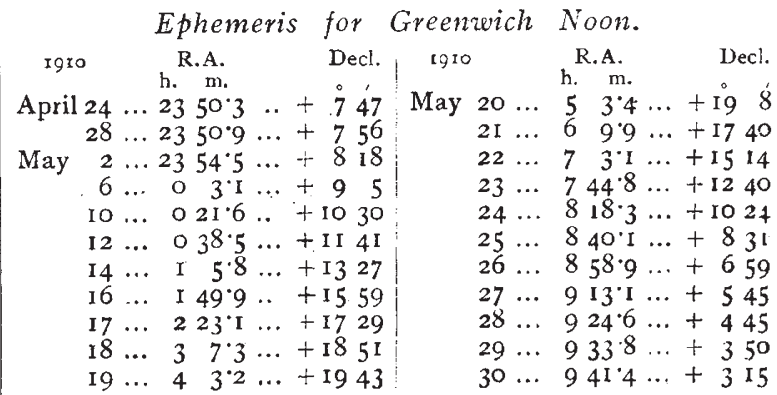

As will be seen from the ephemeris, the comet, when near the sun, will travel very quickly across our line of vision, traversing Aries, Taurus, Orion, and part of Gemini between May 16 and 22 . 